\title{
Molecular imaging of angiogenesis with SPECT
}

\author{
Ingrid Dijkgraaf • Otto C. Boerman
}

Published online: 9 July 2010

(C) The Author(s) 2010. This article is published with open access at Springerlink.com

\begin{abstract}
Single-photon emission computed tomography (SPECT) and position emission tomography (PET) are the two main imaging modalities in nuclear medicine. SPECT imaging is more widely available than PET imaging and the radionuclides used for SPECT are easier to prepare and usually have a longer half-life than those used for PET. In addition, SPECT is a less expensive technique than PET. Commonly used gamma emitters are: ${ }^{99 \mathrm{~m}} \mathrm{Tc}\left(\mathrm{E}_{\max } 141 \mathrm{keV}\right.$, $\left.T_{1 / 2} 6.02 \mathrm{~h}\right),{ }^{123} \mathrm{I}\left(\mathrm{E}_{\max } 529 \mathrm{keV}, T_{1 / 2} 13.0 \mathrm{~h}\right)$ and ${ }^{111} \mathrm{In}$ $\left(\mathrm{E}_{\max } 245 \mathrm{keV}, T_{1 / 2} 67.2 \mathrm{~h}\right)$. Compared to clinical SPECT, PET has a higher spatial resolution and the possibility to more accurately estimate the in vivo concentration of a tracer. In preclinical imaging, the situation is quite different. The resolution of microSPECT cameras $(<0.5 \mathrm{~mm})$ is higher than that of microPET cameras $(>1.5 \mathrm{~mm})$. In this report, studies on new radiolabelled tracers for SPECT imaging of angiogenesis in tumours are reviewed.
\end{abstract}

\section{Keywords Angiogenesis $\cdot \alpha_{\mathrm{v}} \beta_{3} \cdot \mathrm{VEGF} \cdot \mathrm{PMSA} \cdot \mathrm{ECM}$}

\section{Introduction}

Angiogenesis, the formation of new blood vessels from preexisting vasculature, is one of the key requirements if solid tumours are to grow beyond $2-3 \mathrm{~mm}^{3}$, since diffusion is no longer sufficient to supply the tissue with oxygen and nutrients [1]. Tumour-induced angiogenesis is a complex multistep process that follows a characteristic cascade of

I. Dijkgraaf $(\triangle) \cdot$ O. C. Boerman

Department of Nuclear Medicine,

Radboud University Nijmegen Medical Center,

P.O. Box 9101, 6500 HB Nijmegen, The Netherlands

e-mail: I.Dijkgraaf@nucmed.umcn.nl events mediated and controlled by growth factors, cellular receptors and adhesion molecules [2-4]. In this process, five phases can be distinguished: (1) endothelial cell activation, (2) basement membrane degradation, (3) endothelial cell migration, (4) vessel formation and (5) angiogenic remodelling [5].

The activation of pre-existing quiescent vessels can be triggered by hypoxia. Hypoxia induces the expression of hypoxia-inducible factor (HIF), which binds to the hypoxic response element. As a result, the expression of hypoxiainducible genes, such as vascular endothelial growth factor (VEGF), carbonic anhydrase IX (CAIX), platelet-derived growth factor (PDGF) and transforming growth factor- $\alpha$ (TGF- $\alpha$ ), is induced [6].

Activated endothelial cells express the dimeric transmembrane integrin $\alpha_{v} \beta_{3}$, which interacts with extracellular matrix proteins (vitronectin, tenascin, fibronectin, a.o.) and regulates migration of the endothelial cell through the extracellular matrix during vessel formation $[7,8]$. The activated endothelial cells synthesize proteolytic enzymes, such as matrix metalloproteinases (MMPs), used to degrade the basement membrane and the extracellular matrix [9]. Initially, endothelial cells assemble as solid cords. Subsequently, the inner layer of endothelial cells undergoes apoptosis leading to the formation of the vessel lumen. Finally this primary, immature vasculature undergoes extensive remodelling during which the vessels are stabilized by pericytes and smooth muscle cells. This step is often incomplete in tumours resulting in the characteristic, increased permeability of tumour vessels.

Based on a balance between proangiogenic and antiangiogenic factors, a tumour can stay dormant for a very long time period until the so-called angiogenic switch occurs. In most tissues tumours can only grow to a lifethreatening size if the tumour is able to trigger angiogen- 
esis. In tissues with high vessel densities (e.g. liver, brain, a.o.), tumours may also progress via angiogenesisindependent co-option of the pre-existent vasculature [10].

In summary, tumour-induced angiogenesis is a multistep process and a key feature of a tumour lesion that has major impact on the biological behaviour of the lesion. Inhibition of angiogenesis is a new cancer treatment strategy that is now being widely investigated clinically. Researchers have begun to search for objective measures that indicate pharmacological responses to antiangiogenic drugs. Therefore, there is great interest in techniques to visualize angiogenesis in growing tumours non-invasively. During the past decade several markers of angiogenesis have been identified and specific tracers targeting these markers have been developed.

\section{VEGF receptors}

VEGF is a key regulator of angiogenesis during embryogenesis, skeletal growth and reproductive functions. The expression of VEGF is upregulated by environmental stress caused by hypoxia, anaemia, myocardial ischaemia and tumour progression to initiate neovascularization [11]. Via alternative mRNA splicing, the human VEGF-A gene gives rise to four isoforms having 121, 165, 189 and 206 amino acids $\left(\mathrm{VEGF}_{121}, \mathrm{VEGF}_{165}, \mathrm{VEGF}_{189}\right.$ and $\mathrm{VEGF}_{206}$, respectively) $[12,13]$. Less frequent splice variants have been identified more recently, including $\mathrm{VEGF}_{145}$ [14], $\mathrm{VEGF}_{183}$ [15], VEGF ${ }_{162}$ [16] and $\mathrm{VEGF}_{165 \mathrm{~b}}$ [17]. The VEGF isoforms differ not only in their molecular mass, but also in their solubility and receptor-binding characteristics.

Initially, VEGF receptors were identified on the cell surface of vascular endothelial cells in vitro $[18,19]$ and in vivo [20, 21]. Subsequently, it was demonstrated that receptors for VEGF also are expressed on bone marrowderived cells such as monocytes [22]. VEGF-A binds two related receptor tyrosine kinases (RTKs), VEGFR-1 and VEGFR-2. Both receptors consist of seven Ig-like domains in the extracellular domain, a single transmembrane region and a consensus tyrosine kinase sequence that is interrupted by a kinase insert domain [23-25]. VEGFR-1 binds VEGF with a higher affinity compared to VEGFR-2 $\left(\mathrm{K}_{\mathrm{d}}\right.$ : 25 vs 75-250 pM) [26-28]. VEGFR-1 is considered to be a decoy receptor and VEGF-A only signals through VEGFR2 [29].

\section{SPECT imaging of VEGF receptors}

Two VEGF isoforms, VEGF $_{121}$ and $\mathrm{VEGF}_{165}$, have been investigated for their potential to visualize VEGFR expression by SPECT. VEGF 121 and VEGF $_{165}$ were radioiodinated with ${ }^{123} \mathrm{I}$ and the binding properties of ${ }^{123}{\mathrm{I}-\mathrm{VEGF}_{121}}_{1}$ and ${ }^{123}{ }^{2}-V_{E G F} 165$ to human umbilical vein endothelial cells, various human tumour cell lines and a variety of primary human tumours were determined [30].These studies showed that ${ }^{123} \mathrm{I}-V E G F_{121}$ and ${ }^{123} \mathrm{I}_{-} \mathrm{VEGF}_{165}$ specifically bound to various tumour cell types. In comparison with ${ }^{123} \mathrm{I}_{-} \mathrm{VEGF}_{121},{ }^{123}{\mathrm{I}-\mathrm{VEGF}_{165} \text { bound to a }}$ higher number of different tumour cell types with a higher capacity. In a subsequent preliminary clinical study, ${ }^{123} \mathrm{I}-$ VEGF $_{165}$ appeared to be safe and ${ }^{123}$ I-VEGF $_{165}$ visualized gastrointestinal tumours and metastasis expressing VEGF receptors [31]. Although CT/MRI was superior compared to ${ }^{123} \mathrm{I}-V E G F_{165}$ scintigraphy in a lesion-by-lesion comparison, the authors concluded that ${ }^{123} \mathrm{I}-V E G F_{165}$ might be useful for visualization of tumour angiogenesis.

In another clinical study, the biodistribution, safety and absorbed dose of ${ }^{123}{\mathrm{I}-\mathrm{VEGF}_{165}}_{16}$ in patients with pancreatic carcinoma were investigated [32]. A majority of primary pancreatic tumours and their metastases were visualized at $3 \mathrm{~h}$ after ${ }^{123}{ }^{1}-V_{E G F} 165$ administration.

In order to develop non-invasive, specific techniques to estimate tumour vascularity, Yoshimoto and co-workers

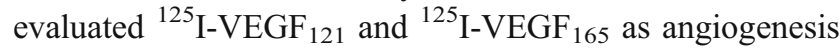
imaging agents in mice with LS180 tumours [33]. ${ }^{125} \mathrm{I}$ VEGF $_{121}$ displayed significantly higher tumour uptake and higher tumour to non-tumour $(\mathrm{T} / \mathrm{N})$ ratios as compared to ${ }^{125} \mathrm{I}-V E G F_{165}$. The tumour accumulation of ${ }^{125}{\mathrm{I}-\mathrm{VEGF}_{121}}_{1}$ decreased with increasing tumour volume. However, in this study it was not investigated whether the uptake of ${ }^{125} \mathrm{I}$ VEGF $_{121}$ and ${ }^{125}$ I-VEGF $_{165}$ in the tumour and other organs and tissues was VEGF receptor-mediated.

Besides radioiodinated VEGF-based isoforms, also VEGF-based isoforms labelled with radiometals such as ${ }^{99 \mathrm{~m}} \mathrm{Tc}$ and ${ }^{111} \mathrm{In}$ have been investigated. Blankenberg and co-workers described a novel imaging complex comprised of a standardized ${ }^{99 \mathrm{~m}} \mathrm{Tc}$-radiolabelled adapter protein noncovalently bound to a "docking tag" fused to a "targeting protein". The assembly of this complex was based on interactions between human 109-amino acid (HuS) and 15amino acid (Hu-tag) fragments of ribonuclease I, which served as an "adapter protein" and a docking tag, respectively. The resulting ${ }^{99 \mathrm{~m}} \mathrm{Tc}-\mathrm{HuS} / \mathrm{Hu}-\mathrm{VEGF}$ complex could be effectively used to image the murine tumour neovasculature in lesions as small as a few millimetres in soft tissue in mice with 4T1-luc tumours [34]. In the same animal model, the HYNIC-conjugated ${ }^{99 \mathrm{~m}}$ Tc-HYNIC-VEGF had a similar biodistribution as the ${ }^{99 \mathrm{~m}} \mathrm{Tc}-\mathrm{HuS} / \mathrm{Hu}-\mathrm{VEGF}$ complex. SPECT imaging using ${ }^{99 \mathrm{~m}} \mathrm{Tc}-\mathrm{HYNIC}-\mathrm{VEGF}$ showed highly heterogeneous focal accumulation in the tumour area. SPECT imaging with ${ }^{99 \mathrm{~m}}$ Tc-HYNIC-VEGF could also readily detect the effects of chemotherapeutic treatment of 4T1 tumours [35]. Binding specificity was confirmed by the $75 \%$ decrease in tumour uptake of ${ }^{99 \mathrm{~m}} \mathrm{Tc}$-biotin-inactivated VEGF, as compared to ${ }^{99 \mathrm{~m}} \mathrm{Tc}-\mathrm{HYNIC}$-VEGF. 
Chan et al. synthesized a recombinant protein VEGF composed of $\mathrm{VEGF}_{165}$ fused through a flexible polypeptide linker (GGGGS) $)_{3}$ to the n-lobe of human transferrin (hnTf) for imaging angiogenesis [36]. The VEGF construct was conjugated to the n-lobe of hnTf to allow labelling with ${ }^{111} \mathrm{In}$ at a site remote from the VEGF receptor-binding domain. ${ }^{111}$ In-hnTf-VEGF accumulated in U87MG glioblastoma xenografts $[6.7 \% \mathrm{ID} / \mathrm{g}, 72 \mathrm{~h}$ post-injection (p.i.)] in athymic mice and its tumour uptake decreased 15 -fold by coadministration of a 100-fold excess VEGF, indicating that the tracer specifically accumulated in U87MG tumours.

The studies described above were all done with VEGF isoforms. Alternatively, studies with radiolabelled antiVEGF antibodies and derivatives thereof have also been reported. Bevacizumab is a humanized variant of the antiVEGF-A monoclonal antibody (mAb) A.4.6.1. It is directed against a common epitope encoded by exon 4, present on all VEGF isoforms, and prevents interaction of VEGF with VEGFR-1 and VEGFR-2 [37]. Nagengast et al. were the first to demonstrate non-invasive VEGF imaging using radiolabelled bevacizumab. In their study, they demonstrated the potential of ${ }^{89} \mathrm{Zr}$-bevacizumab and ${ }^{111}$ In-bevacizumab as a specific VEGF tracer in nude mice with human SKOV-3 ovarian tumour xenografts [38]. At the same time, our group showed specific imaging of VEGF-A expression using ${ }^{111}$ In-bevacizumab in mice with s.c. human colon carcinoma xenografts LS174T [39]. We were the first to investigate the potential of ${ }^{111}$ In-labelled bevacizumab to image the expression of VEGF-A in tumours in cancer patients. In a study in colorectal cancer patients with liver metastases, the liver metastases in 9 of 12 patients were visualized with ${ }^{111}$ In-bevacizumab (Fig. 1). In this study, the liver metastases were resected after scintigraphic imaging allowing further immunohistochemical analysis. The VEGF-A expression in these resected liver metastases was determined by in situ hybridization and by measuring VEGF in tumour extracts by enzyme-linked immunosorbent assay (ELISA). Surprisingly, no correlation was found between the level of antibody accumulation and the level of VEGF-A expression.

In a preclinical study, the biodistribution of ${ }^{111} \mathrm{In}$ labelled bevacizumab and ${ }^{111}$ In-labelled ranibizumab, an anti-VEGF Fab fragment, were compared in nude mice with SKOV-3 ovarian tumours. Although bevacizumab showed the highest tumour uptake, ranibizumab allowed imaging earlier after injection of the tracer, making the Fab fragment tracer more suited to monitor rapid changes of VEGF expression following therapy. SPECT imaging using

${ }^{111}$ In-labelled bevacizumab revealed tumour lesions in both melanoma and metastatic colon cancer patients [40].

\section{$\alpha_{v} \beta_{3}$ integrin receptor}

The $\alpha_{v} \beta_{3}$ integrin, also referred to as the vitronectin receptor, belongs to the integrin receptors. Integrins are a family of heterodimeric transmembrane glycoproteins that function in cellular adhesion, migration and signal transduction. Each member of this family consists of two noncovalently bound transmembrane polypeptide subunits, alpha and beta.

Activated endothelial cells express the integrin $\alpha_{v} \beta_{3}$ receptor, whereas this integrin receptor is absent on quiescent endothelial cells. In addition, $\alpha_{\mathrm{v}} \beta_{3}$ is expressed on the cell membrane of various tumour cell types such as: ovarian cancer, neuroblastoma, breast cancer, melanoma, a.o. $\alpha_{\mathrm{v}} \beta_{3}$ Integrin expressed on endothelial cells modulates cell migration and survival during angiogenesis, whereas $\alpha_{\mathrm{v}} \beta_{3}$ integrin expressed on carcinoma cells potentiates metastasis by facilitating invasion and movement across blood vessels. Due to this restricted expression of $\alpha_{v} \beta_{3}$ in tumours, $\alpha_{\mathrm{v}} \beta_{3}$ is considered a suitable target for imaging angiogenesis [41]. Radiolabelled ligands for this integrin can be used as tracers to non-invasively visualize $\alpha_{v} \beta_{3}$ expression in tumours. Non-invasive visualization of $\alpha_{v} \beta_{3}$ expression might provide information about the angiogenic
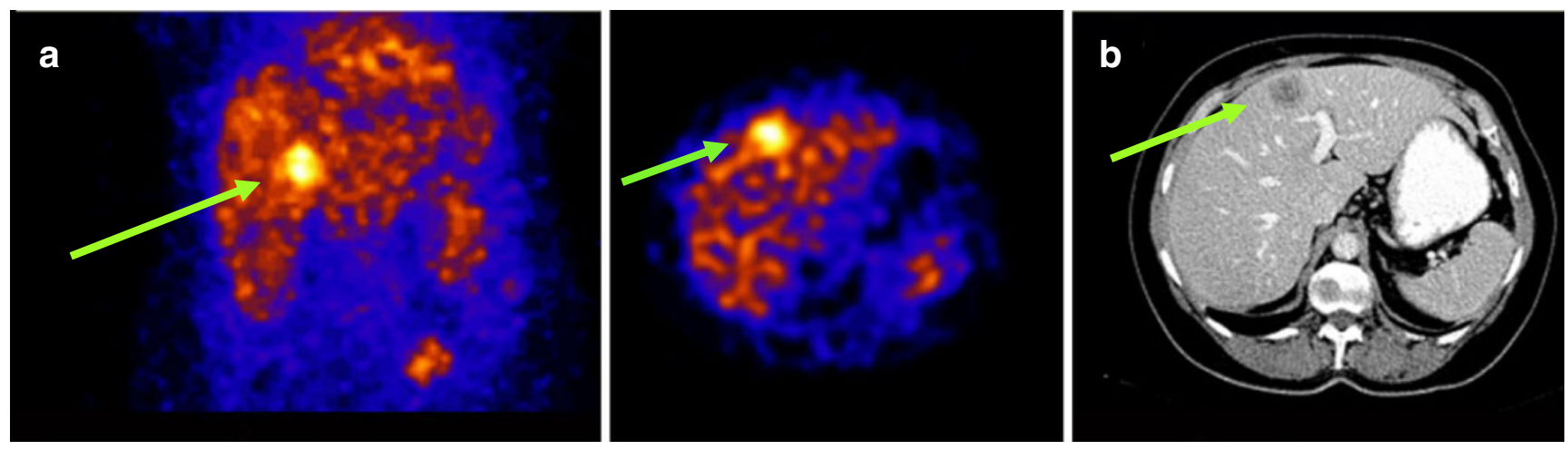

Fig. 1 a Scintigraphic imaging of a liver metastasis with ${ }^{111}$ In-bevacizumab. b Four-phase CT scan: imaging of liver metastasis 
process and the responsiveness of a tumour to antiangiogenic drugs.

\section{SPECT imaging of $\alpha_{\mathrm{v}} \beta_{3}$ expression}

Integrin $\alpha_{v} \beta_{3}$ binds extracellular matrix proteins (e.g. vitronectin, fibrinogen, laminin, collagen) through exposed tripeptide arginine-glycine-aspartic acid (RGD) amino acid moieties [42]. Several research groups have investigated the potential of RGD-containing peptides to target $\alpha_{\mathrm{v}} \beta_{3}$ expressed in tumours with radionuclides. It was found that the cyclic pentapeptide cyclo(Arg-Gly-Asp-D-Phe-Val), having an $\mathrm{IC}_{50}$ value in the lower nanomolar range, was a 100 -fold better inhibitor of cell adhesion to vitronectin compared to the linear variant $[43,44]$. It was found that besides the essential RGD sequence, a hydrophobic amino acid in position 4 increases the affinity for $\alpha_{v} \beta_{3}$ [45]. Based on this finding Haubner and co-workers designed five peptides that could be radioiodinated by introducing a tyrosine residue. Two of these peptides, cyclo(Arg-GlyAsp-D-Tyr-Val) and cyclo(Arg-Gly-Asp-D-Phe-Tyr) (designated as $\mathrm{P} 1$ and $\mathrm{P} 4$, respectively) were studied in vivo [46]. The biodistribution of the radioiodinated peptides was studied in nude mice with various s.c. human tumours (M21 melanoma, MaCaF mammary carcinoma and osteosarcoma). The peptides rapidly cleared from the blood $(<1 \% \mathrm{ID} / \mathrm{g}$ at $10 \mathrm{~min}$ p.i.). In the M21 melanoma model, the tumour uptake peaked at $10 \mathrm{~min}$ p.i. $(1.12 \pm 0.98 \% \mathrm{ID} / \mathrm{g})$ and decreased to $0.12 \pm 0.04 \% \mathrm{ID} / \mathrm{g}$ at $2 \mathrm{~h}$ p.i. However, both peptides cleared via the hepatobiliary route and revealed relatively high hepatic uptake, especially at early time points ( $\sim 5 \% \mathrm{ID} / \mathrm{g}, 1 \mathrm{~h} \mathrm{p}$.i.). Therefore, the pharmacokinetics of these RGD peptides were improved by conjugating them with sugar amino acids. A glucose-based sugar amino acid (SAA1) was conjugated to the epsilon-amino function of lysine in the pentapeptide. Compared to the non-carbohydrate radioiodinated $\mathrm{P} 4$, the resulting iodine-labelled glycopeptide 3-[*I]iodo-D-Tyr4-cyclo(Arg-Gly-Asp-D-Tyr-Lys (SAA1)) (*I-gluco-RGD) showed reduced activity accumulation in the liver, enhanced blood levels and increased uptake and retention in the tumour [47]. Based on these data a galactosebased sugar amino acid (SAA2) was conjugated with cyclo (Arg-Gly-Asp-D-Phe-Lys) allowing prosthetic group labelling $[47,48]$.

van Hagen and co-workers conjugated a DTPA moiety via the epsilon group of the lysine residue in the cyclic pentapeptide cyclo(Arg-Gly-Asp-D-Tyr-Lys). The resulting ligand could be radiolabelled with both ${ }^{111} \mathrm{In}$ and radioiodine. The radiolabelled peptide bound specifically to $\alpha_{v} \beta_{3}$-positive cells. DTPA conjugation made the peptide more hydrophilic and facilitated renal clearance, in contrast to the non-DTPA-conjugated radioiodinated peptide which cleared predominantly via the hepatobiliary route [49].
An alternative lead structure compared to the head-to-tail cyclized RGD-containing pentapeptide is the disulphidebridged RGD-4C $\left(\mathrm{Cys}^{2}-\mathrm{Cys}^{10}{ }^{10} \mathrm{Cys}^{4}-\mathrm{Cys}^{8}\right)$ H-Ala-Cys-AspCys-Arg-Gly-Asp-Cys-Phe-Cys-Gly-OH which binds with high affinity to both $\alpha_{\mathrm{v}} \beta_{3}$ and $\alpha_{\mathrm{v}} \beta_{5}\left(\mathrm{~K}_{\mathrm{D}} \sim 100 \mathrm{nM}\right)$ [50]. Its derivative (Cys $\left.{ }^{1}-\mathrm{Cys}^{9}, \mathrm{Cys}^{3}-\mathrm{Cys}^{7}\right) \mathrm{H}-\mathrm{Cys}-\mathrm{Asp}$-Cys-ArgGly-Asp-Cys-Phe-Cys-OH was conjugated with HYNIC and subsequently radiolabelled with ${ }^{99 \mathrm{~m}} \mathrm{Tc}$. In in vivo studies, this ${ }^{99 \mathrm{~m}} \mathrm{Tc}-\mathrm{HYNIC}-\mathrm{RGD}$ had marginal tumour uptake in mice with $\alpha_{v} \beta_{3}$-positive tumours [51, 52]. The deletion of the terminal amino acids, the conjugation with HYNIC and/or the labelling with ${ }^{99 \mathrm{~m}} \mathrm{Tc}$ could have impaired the affinity of the peptide for the receptor.

\section{Clinical studies}

Sivolapenko and colleagues were the first who investigated the synthetic linear RGD analogue $\alpha \mathrm{P} 2$ (Arg-Gly-Asp-SerCys-Arg-Gly-Asp-Ser-Tyr) to image tumour angiogenesis in patients $[53,54]$. Fourteen melanoma patients received 185-1222 MBq of the ${ }^{99 \mathrm{~m}} \mathrm{Tc}$-labelled peptide intravenously (i.v.) and were imaged up to $3 \mathrm{~h}$ p.i. The peptide cleared rapidly from the blood $\left(T_{1 / 2} \alpha=5.5 \pm 2.2 \mathrm{~min}\right.$ and $T_{1 / 2} \beta=$ $34.3 \pm 11.0 \mathrm{~min}$ ) by filtration through the kidneys and excretion in the urine ( $>90 \% \mathrm{ID}$ in kidneys and bladder at $1 \mathrm{~h}$ p.i.). Of the 22 metastatic lesions in these patients, 17 were visualized.

The ${ }^{99 \mathrm{~m}}$ Tc-labelled RGD-containing peptide (NC100692, Fig. 2) was evaluated in ischaemic models and showed high uptake in areas of neovascularization with $\alpha_{v} \beta_{3}$ integrin overexpression [55]. In these models it was shown that $\mathrm{NC100692}$ bound to $\alpha_{v} \beta_{3}$-expressing endothelial cells in regions of angiogenesis [56].

Subsequently, ${ }^{99 \mathrm{~m}} \mathrm{Tc}-\mathrm{NC} 100692$ was tested in women with histologically proven breast cancer. ${ }^{99 \mathrm{~m}} \mathrm{Tc}-\mathrm{NC} 100692$ detected malignant breast tumours efficiently [57]. Of 20 malignant tumours, 19 were detected and there were no safety concerns related to the administration of ${ }^{99 \mathrm{~m}} \mathrm{Tc}-\mathrm{NC} 100692$ [58].

To determine the feasibility of detecting metastatic lesions in liver, lung, bone and brain with scintigraphy, ${ }^{99 \mathrm{~m}} \mathrm{Tc}-\mathrm{NC} 100692$ was used in an open-label, multicentre, phase 2a study in late-stage cancer patients [59]. Therefore, 25 patients, 15 with lung cancer and 10 with breast cancer, were recruited at 10 centres. In patients with breast cancer, ${ }^{99 \mathrm{~m}} \mathrm{Tc}-\mathrm{NC} 100692$ scintigraphy detected 1 of 7 liver, 4 of 5 lung, 8 of 17 bone and 1 of 1 brain metastases. The corresponding numbers in lung cancer patients were 0 of 2 , 17 of 18,2 of 2 and 7 of 9 . Despite the low number of patients with liver metastases included in this study, the authors concluded that the sensitivity to detect liver metastases was poor and the detection of bone metastases is equivocal with ${ }^{99 \mathrm{~m}} \mathrm{Tc}-\mathrm{NC} 100692$. However, it was feasible to detect lung and brain metastases from breast and lung cancer. 

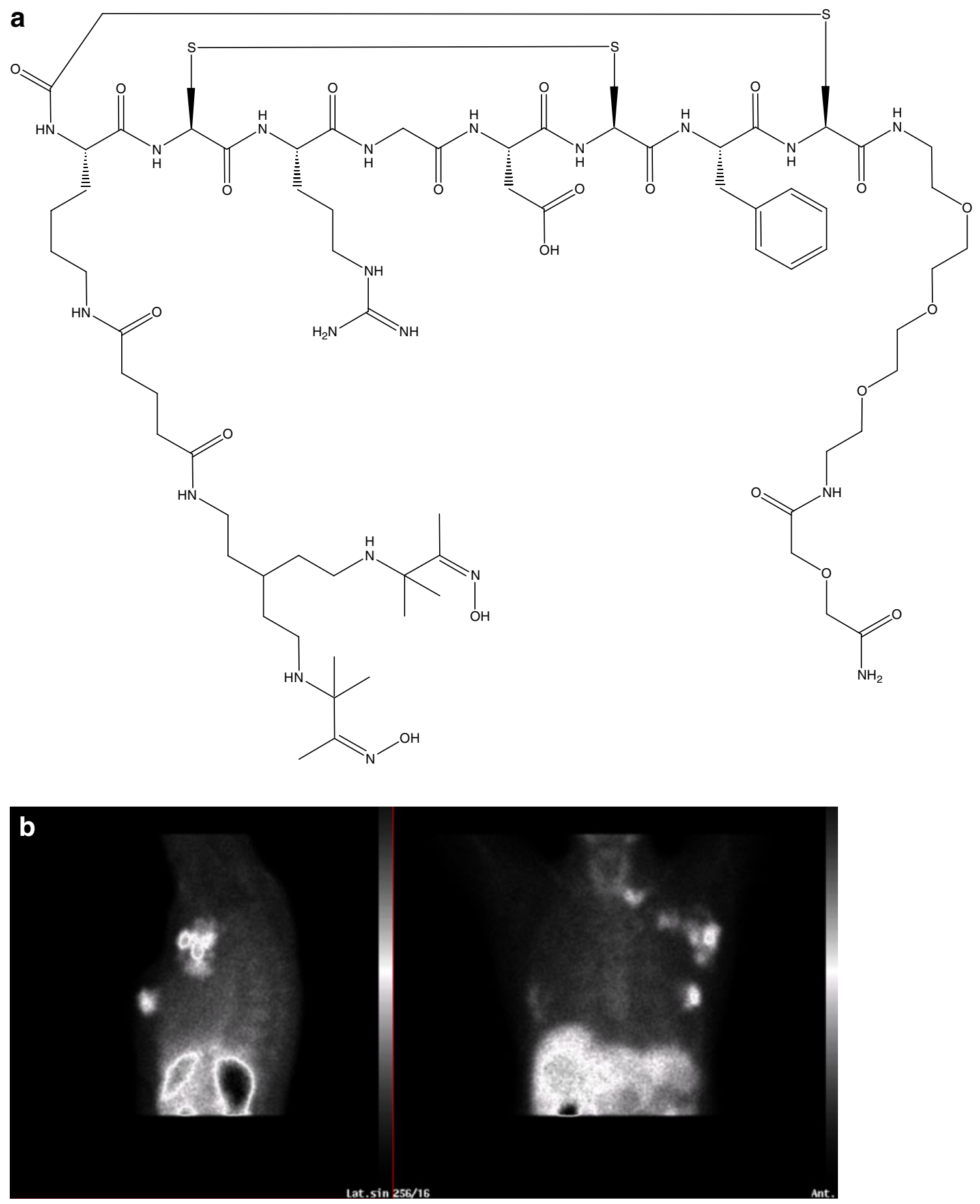

Fig. 2 a Structural formula of NC100692. b Patient with uptake of 99mTc-NC100692 in cancer in the left breast, axillary and subclavicular lymf nodes (This image was kindly provided by Dr. Rimma Axelsson, Division of Radiology, Karolinska Institutet, Stockholm, Sweden)

\section{Multivalent $c y c l o($ RGD) peptides}

To improve tumour targeting and to obtain better in vivo imaging properties, several research groups aimed to enhance the affinity toward the $\alpha_{v} \beta_{3}$ integrin by using multimeric RGD peptides. Janssen et al. conjugated two cyclo(RGDfK) peptides via a glutamic acid linker, conju- gated it with HYNIC and radiolabelled it with ${ }^{99 \mathrm{~m}} \mathrm{Tc}$. The dimeric ${ }^{99 \mathrm{~m}}$ Tc-HYNIC-E-[c(RGDfK) $]_{2}$ showed a tenfold higher affinity for $\alpha_{v} \beta_{3}$ and a better retention than the monomeric ${ }^{99 \mathrm{~m}}$ Tc-HYNIC-E-c(RGDfK) [60]. However, the dimer also had higher uptake in the kidneys. Possibly, the presence of more guanidine groups in the dimer caused the enhanced renal uptake [61]. 
In another study, the tumour targeting potential of both a ${ }^{111}$ In- and ${ }^{99 m}$ Tc-labelled dimeric RGD peptide derivatized with the chelators DOTA or HYNIC, respectively, was investigated in mice with s.c. NIH:OVCAR-3 tumours [62]. Tumour uptake peaked at $7.5 \% \mathrm{ID} / \mathrm{g}$ for ${ }^{111} \mathrm{In}$-DOTA-E-[c (RGDfK) $]_{2}\left(2 \mathrm{~h} \mathrm{p}\right.$.i.) and $6.0 \% \mathrm{ID} / \mathrm{g}$ for ${ }^{99 \mathrm{~m}} \mathrm{Tc}-\mathrm{HYNIC}-\mathrm{E}-[\mathrm{c}$ $(\text { RGDfK) }]_{2}$ (1 h p.i.).

The multivalency effect was further explored by the synthesis of the DOTA-conjugated tetrameric analogue $\mathrm{E}\{\mathrm{E}$ $\left.[\mathrm{c}(\mathrm{RGDfK})]_{2}\right\}_{2}[63]$. The in vitro affinity and the in vivo tumour targeting characteristics of the ${ }^{111}$ In-labelled mono-, di- and tetramer to $\alpha_{v} \beta_{3}$-expressing tumours were determined ( $\mathrm{IC}_{50}$ values; monomer: $120 \mathrm{nM}$, dimer: $69.9 \mathrm{nM}$ and tetramer: $19.6 \mathrm{nM})$. The tetramer showed improved tumour targeting $(7.40 \pm 1.12 \% \mathrm{ID} / \mathrm{g})$ compared to the dimer $(5.17 \pm 1.22 \% \mathrm{ID} / \mathrm{g}$ at $8 \mathrm{~h}$ p.i.). Analogously, the dimer demonstrated improved tumour targeting compared to the monomer $(2.30 \pm 0.34 \% \mathrm{ID} / \mathrm{g}$ at 8 h p.i., Fig. 3$)$.

The application of dimers and tetramers as SPECT radiotracers by tethering together $\mathrm{c}(\mathrm{RGDfK})$ units via a

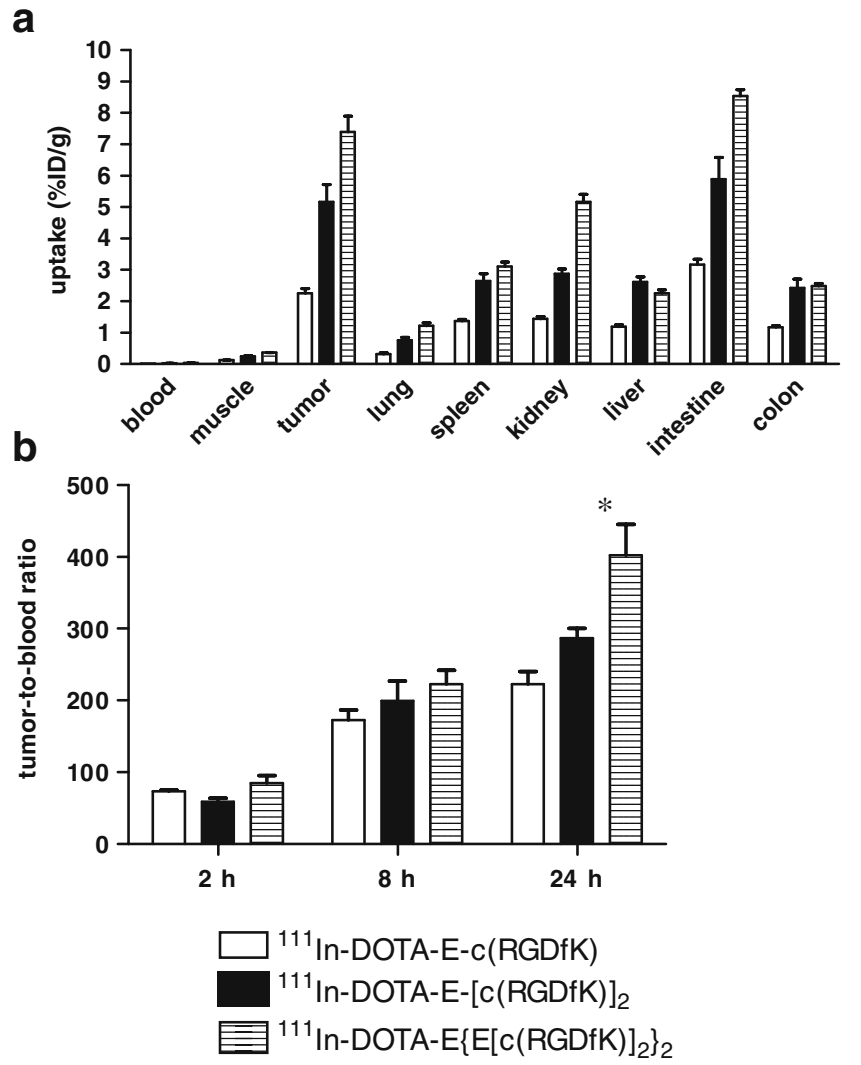

Fig. 3 a Biodistribution of ${ }^{111}$ In-DOTA-E-c(RGDfK), ${ }^{111}$ In-DOTA$\mathrm{E}-[\mathrm{c}(\mathrm{RGDfK})]_{2}$ and ${ }^{111} \mathrm{In}-\mathrm{DOTA}-\mathrm{E}\left\{\mathrm{E}[\mathrm{c}(\mathrm{RGDfK})]_{2}\right\}_{2}$ at $8 \mathrm{~h}$ p.i. in athymic mice with s.c. SK-RC-52 tumours (5 mice/group). b Tumour to blood ratios of ${ }^{111}$ In-DOTA-E-c(RGDfK), ${ }^{111}$ In-DOTA-E-[c $(\mathrm{RGDfK})]_{2}$ and ${ }^{111}$ In-DOTA-E $\left\{\mathrm{E}[\mathrm{c}(\mathrm{RGDfK})]_{2}\right\}_{2}$ at 2,8 and $24 \mathrm{~h}$ after injection in athymic mice with s.c. SK-RC-52 tumours. Each bar represents the mean values $\pm \mathrm{SD}$. Values were analysed using one-way analysis of variance, ${ }^{*} p<0.05$ glutamic acid tree has been studied extensively. Recently, a variety of $\mathrm{c}(\mathrm{RGDfK})$ multimers assembled via the RAFT template [64] or click chemistry [65] was studied as well. In all of the multimeric RGD studies described above, it was found that multimerization of cyclic RGD peptides enhanced their integrin $\alpha_{v} \beta_{3}$-binding affinity and improved the tumour uptake of the radiotracer. However, the uptake of the radiotracers in kidney and liver also increased significantly as the peptide multiplicity increased. In addition, the synthesis of the $c($ RGDxK)-based tetra- and octamers $(\mathrm{x}=\mathrm{f}$ or $\mathrm{y})$ is much more complicated and could limit their introduction into clinical practice.

In general, there are two main factors that contribute to a higher $\alpha_{v} \beta_{3}$-binding affinity of multimeric RGD peptides compared to their monomeric counterparts: (1) simultaneous $\alpha_{v} \beta_{3}$ integrin binding by two RGD motifs or (2) the locally enriched RGD concentration. To achieve simultaneous integrin $\alpha_{\mathrm{v}} \beta_{3}$ binding (=multivalency), the distance between the RGD motifs in multimeric RGD peptides must be long enough and flexible enough. There are some disadvantages of using tetra- or octameric RGD peptides over their dimeric counterparts, such as the more complicated synthesis and higher uptake in non-target organs. To solve these problems, pharmacokinetic modifier (PKM) linkers between the two RGD motifs in dimeric RGD peptides have been tested in several studies.

In an attempt to increase the affinity of $E[c(R G D f K)]_{2}$, Shi and co-workers developed a series of cyclic RGD dimers containing triglycine $\left(\mathrm{G}_{3}\right)$ and $\mathrm{PEG}_{4}$ linkers, which were used to increase the distance between two cyclic RGD units from 6 bonds in $\mathrm{E}$ [c(RGDfK) $]_{2}$ to 24 bonds in $3 \mathrm{G}_{3^{-}}$ dimer and 38 bonds in $3 \mathrm{PEG}_{4}$-dimer $[66,67]$. In in vitro binding studies on U87MG human glioma cells, the linkercontaining dimers HYNIC-3PEG ${ }_{4}$-dimer $\left(\mathrm{IC}_{50}=60 \pm 4 \mathrm{nM}\right)$ and $\mathrm{HYNIC}-3 \mathrm{G}_{3}$-dimer $\left(\mathrm{IC}_{50}=61 \pm 2 \mathrm{nM}\right)$ had a higher affinity than $\mathrm{HYNIC}-\mathrm{PEG}_{4}$-dimer $\left(\mathrm{IC}_{50}=84 \pm 7 \mathrm{nM}\right)$, which had a short linker between the RGD units. The HYNICtetramer had a higher binding affinity $\left(\mathrm{IC}_{50}=7 \pm 2 \mathrm{nM}\right)$ probably due to its two extra RGD units. In mice with s.c. U87MG glioma and MDA-MB-435 breast tumour xenografts, the tumour uptake of ${ }^{99 \mathrm{~m}} \mathrm{Tc}-\mathrm{HYNIC}-3 \mathrm{PEG}_{4}$-dimer and ${ }^{99 \mathrm{~m}} \mathrm{Tc}-\mathrm{HYNIC}-3 \mathrm{G}_{3}$-dimer was similar to that of the ${ }^{99 \mathrm{~m}} \mathrm{Tc}-\mathrm{HYNIC}$-tetramer, indicating divalent binding of the three tracers. The tumour uptake of the ${ }^{99 \mathrm{~m}} \mathrm{Tc}$-HYNIC$\mathrm{PEG}_{4}$-dimer was much lower, suggesting monovalent binding. Furthermore, ${ }^{99 \mathrm{~m}} \mathrm{Tc}-\mathrm{HYNIC}-3 \mathrm{PEG}_{4}$-dimer and ${ }^{99 \mathrm{~m}}$ Tc-HYNIC-3 $\mathrm{G}_{3}$-dimer had kidney and liver uptake that was half of that of the ${ }^{99 \mathrm{~m}} \mathrm{Tc}-\mathrm{HYNIC}$-tetramer. In a subsequent study, ${ }^{111}$ In-DOTA-3PEG 4 -dimer, ${ }^{111}$ In-DTPA$3 \mathrm{PEG}_{4}$-dimer and ${ }^{111}$ In-DTPA-Bn-3PEG 4 -dimer were synthesized and compared in in vitro and in vivo studies [68]. The affinities were $1.3 \pm 0.2,1.4 \pm 0.3$ and $1.3 \pm 0.3 \mathrm{nM}$, respectively. In mice with s.c. U87MG glioma xenografts, 
all three radiotracers had a high tumour uptake and excellent tumour to background (T/B) ratios up to $4 \mathrm{~h}$ p.i. After that time point, both DTPA-conjugated derivatives showed a much faster tumour washout and poorer T/B ratios than the DOTA-conjugated derivative.

So far, $3 \mathrm{PEG}_{4}$-dimer and $3 \mathrm{G}_{3}$-dimer seem suitable candidates for SPECT imaging of angiogenesis in clinical studies.

\section{Extracellular matrix proteins}

A few antigens in the extracellular matrix (ECM) have been identified that are preferentially expressed in the surroundings of newly formed blood vessels, such as fibronectin, laminin, tenascin and collagen type IV. A series of SPECT tracers targeting the extra domain $\mathrm{B}$ of fibronectin for imaging tumour angiogenesis have been developed

\section{Extra domain B of fibronectin}

Fibronectin is a large glycoprotein in the ECM. The extra domain B (ED-B) of fibronectin is a sequence of 91 amino acids, identical in mice, rats and humans, that is inserted into the fibronectin molecule at sites of tissue remodelling due to alternative splicing. ED-B is specifically expressed around neovascular structures in tumours and other tissues undergoing angiogenesis, but is undetectable in normal adult tissues. Using phage display technology, single-chain antibodies ( $\mathrm{scFv}$ ) directed against ED-B have been isolated. The human single domain antibody (scFv) L19 was shown to have subnanomolar affinity for ED-B [69].

Demartis et al. showed that radioiodinated $\mathrm{scFv}$ L19 selectively accumulated around tumoural blood vessels in a murine tumour model. Since the ED-B domain of fibronectin has an identical sequence in mouse and man, they suggested clinical utility for the scintigraphic detection of angiogenesis in vivo [70]. Two years later, it was shown by scintigraphic imaging that ${ }^{123}$ I-L19 selectively localized in tumour lesions of aggressive lung cancer as well as in liver metastases of colorectal cancer patients [71]. More recently, the amino acid sequence (Gly)3-Cys-Ala was inserted at the $\mathrm{C}$ terminus of L19, resulting in the anti-ED-B scFv named AP39, which could be labelled with ${ }^{99 \mathrm{~m}} \mathrm{Tc}$. The data revealed the feasibility of targeting ED-B fibronectin with ${ }^{99 \mathrm{~m}}$ Tc-labelled L19 in nude mice with s.c. teratocarcinoma tumours [72].

Subsequently a series of different L19 antibody formats were constructed, including dimeric $\mathrm{scFv}$, a human bivalent "small immunoprotein" (SIP) and a complete human IgG. In comparing these different formats labelled with ${ }^{125} \mathrm{I} /{ }^{131} \mathrm{I}$, L19-SIP proved to be the most suitable tracer for imaging ED-B expression in tumours.

\section{Prostate-specific membrane antigen}

Prostate-specific membrane antigen (PSMA) is a transmembrane protein which is overexpressed in prostate cancer. The anti-PSMA antibody, capromab pendetide, labelled with ${ }^{111}$ In is marketed as ProstaScint ${ }^{\circledR}$, an antibody preparation approved by the US Food and Drug Administration (FDA) for the detection of nodal metastases in prostate cancer patients [73]. However, this antibody is directed against an intracellular epitope of PSMA, which is considered a suboptimal target for antibody imaging. PSMA was also found to be expressed on the neovascular endothelium of most solid tumour types, while there is no expression on the endothelial cells of normal tissue [74].

J591 is a monoclonal antibody directed against an epitope on the extracellular domain of PSMA [75]. Previous studies have shown that J591 accumulated in metastatic prostate cancer lesions [76]. In a recent phase I trial the feasibility of targeting the neovasculature of a wide range of adenocarcinomas using ${ }^{111}$ In-labelled humanized J591 was investigated. Patients with melanoma and cancers of the breast, colon, liver and kidney received ${ }^{111}$ In-J591. In these patients $(n=24)$ the antibody accreted in all known tumour sites. Of 18 patients with soft tissue disease on standard scans, 17 (94\%) showed uptake in the soft tissues on antibody scans as did 6 of 6 patients with bone disease. These data show selective targeting of PSMA expressed on tumour endothelium [77]. ${ }^{111}$ In-huJ591 has the potential to become a suitable tracer for imaging angiogenesis.

\section{Conclusions}

In the last few years, significant progress has been made in the development of SPECT tracers (peptides, proteins and antibodies) for the non-invasive imaging of tumour angiogenesis. These tracers might have the potential to select patients who might benefit from treatment with antiangiogenic drugs and these tracers might also be used to therapeutic effect with these antiangiogenic drugs. Small animal SPECT cameras have a higher resolution than microPET cameras and in the clinical situation the difference in resolution is marginal. PET isotopes are more expensive than SPECT isotopes and single photon agents can provide more specific targeting abilities than PET agents, by enabling dual-tracer imaging, which is still unique to SPECT.

\section{Conflicts of interest None.}

Open Access This article is distributed under the terms of the Creative Commons Attribution Noncommercial License which permits any noncommercial use, distribution, and reproduction in any medium, provided the original author(s) and source are credited. 


\section{References}

1. Ferrara N. Vascular endothelial growth factor and the regulation of angiogenesis. Recent Prog Horm Res 2000;55:15-35.

2. Kuwano M, Fukushi J, Okamoto M, Nishie A, Goto H, Ishibashi T, et al. Angiogenesis factors. Intern Med 2001;40:565-72.

3. Ellis LM, Liu W, Ahmad SA, Fan F, Jung YD, Shaheen RM, et al. Overview of angiogenesis: biologic implications for antiangiogenic therapy. Semin Oncol 2001;28:94-104. Review.

4. Yancopoulos GD, Davis S, Gale NW, Rudge JS, Wiegand SJ, Holash J. Vascular-specific growth factors and blood vessel formation. Nature 2000;407:242-8. Review.

5. Carmeliet P. Mechanisms of angiogenesis and arteriogenesis. Nat Med 2000;6:389-95. Review.

6. Harris AL. Hypoxia-a key regulatory factor in tumour growth. Nat Rev Cancer 2002;2:38-47. Review.

7. Eliceiri BP, Cheresh DA. The role of alphav integrins during angiogenesis. Mol Med 1998;4:741-50. Review.

8. Hynes RO, Bader BL, Hodivala-Dilke K. Integrins in vascular development. Braz J Med Biol Res 1999;32:501-10. Review.

9. Pepper MS. Role of the matrix metalloproteinase and plasminogen activator-plasmin systems in angiogenesis. Arterioscler Thromb Vasc Biol 2001;21:1104-17. Review.

10. Leenders WP, Küsters B, de Waal RM. Vessel co-option: how tumors obtain blood supply in the absence of sprouting angiogenesis. Endothelium 2002;9:83-7.

11. Ferrara N. The role of VEGF in the regulation of physiological and pathological angiogenesis. EXS 2005;94:209-31. Review.

12. Houck KA, Ferrara N, Winer J, Cachianes G, Li B, Leung DW. The vascular endothelial growth factor family: identification of a fourth molecular species and characterization of alternative splicing of RNA. Mol Endocrinol 1991;5:1806-14.

13. Tischer E, Mitchell R, Hartman T, Silva M, Gospodarowicz D, Fiddes JC, et al. The human gene for vascular endothelial growth factor. Multiple protein forms are encoded through alternative exon splicing. J Biol Chem 1991;266:11947-54.

14. Poltorak Z, Cohen T, Sivan R, Kandelis Y, Spira G, Vlodavsky I, et al. VEGF145, a secreted vascular endothelial growth factor isoform that binds to extracellular matrix. J Biol Chem 1997;272: 7151-8.

15. Jingjing L, Xue Y, Agarwal N, Roque RS. Human Müller cells express VEGF183, a novel spliced variant of vascular endothelial growth factor. Invest Ophthalmol Vis Sci 1999;40:752-9.

16. Lange T, Guttmann-Raviv N, Baruch L, Machluf M, Neufeld G. VEGF162, a new heparin-binding vascular endothelial growth factor splice form that is expressed in transformed human cells. J Biol Chem 2003;278:17164-9.

17. Bates DO, Cui TG, Doughty JM, Winkler M, Sugiono M, Shields JD, et al. VEGF165b, an inhibitory splice variant of vascular endothelial growth factor, is down-regulated in renal cell carcinoma. Cancer Res 2002;62:4123-31.

18. Plouët J, Moukadiri H. Characterization of the receptor to vasculotropin on bovine adrenal cortex-derived capillary endothelial cells. J Biol Chem 1990;265:22071-4.

19. Vaisman N, Gospodarowicz D, Neufeld G. Characterization of the receptors for vascular endothelial growth factor. J Biol Chem 1990;265:19461-6.

20. Jakeman LB, Winer J, Bennett GL, Altar CA, Ferrara N. Binding sites for vascular endothelial growth factor are localized on endothelial cells in adult rat tissues. J Clin Invest 1992;89:244-53.

21. Jakeman LB, Armanini M, Phillips HS, Ferrara N. Developmental expression of binding sites and messenger ribonucleic acid for vascular endothelial growth factor suggests a role for this protein in vasculogenesis and angiogenesis. Endocrinology 1993;133: $848-59$.
22. Ferrara N, Davis-Smyth T. The biology of vascular endothelial growth factor. Endocr Rev 1997;18:4-25. Review.

23. Shibuya M, Yamaguchi S, Yamane A, Ikeda T, Tojo A, Matsushime $\mathrm{H}$, et al. Nucleotide sequence and expression of a novel human receptor-type tyrosine kinase gene (flt) closely related to the fms family. Oncogene 1990;5:519-24.

24. Matthews W, Jordan CT, Gavin M, Jenkins NA, Copeland NG, Lemischka IR. A receptor tyrosine kinase cDNA isolated from a population of enriched primitive hematopoietic cells and exhibiting close genetic linkage to c-kit. Proc Natl Acad Sci U S A 1991;88:9026-30.

25. Terman BI, Carrion ME, Kovacs E, Rasmussen BA, Eddy RL, Shows TB. Identification of a new endothelial cell growth factor receptor tyrosine kinase. Oncogene 1991;6:1677-83.

26. Terman BI, Dougher-Vermazen M, Carrion ME, Dimitrov D, Armellino DC, Gospodarowicz D, et al. Identification of the KDR tyrosine kinase as a receptor for vascular endothelial cell growth factor. Biochem Biophys Res Commun 1992;187:1579-86.

27. Quinn TP, Peters KG, De Vries C, Ferrara N, Williams LT. Fetal liver kinase 1 is a receptor for vascular endothelial growth factor and is selectively expressed in vascular endothelium. Proc Natl Acad Sci U S A 1993;90:7533-7.

28. Millauer B, Wizigmann-Voos S, Schnürch H, Martinez R, Møller NP, Risau W, et al. High affinity VEGF binding and developmental expression suggest Flk-1 as a major regulator of vasculogenesis and angiogenesis. Cell 1993;72:835-46.

29. Shibuya M, Claesson-Welsh L. Signal transduction by VEGF receptors in regulation of angiogenesis and lymphangiogenesis. Exp Cell Res 2006;312:549-60.

30. Li S, Peck-Radosavljevic M, Koller E, Koller F, Kaserer K, Kreil A, et al. Characterization of (123)I-vascular endothelial growth factor-binding sites expressed on human tumour cells: possible implication for tumour scintigraphy. Int J Cancer 2001;91:789-96.

31. Li S, Peck-Radosavljevic M, Kienast O, Preitfellner J, Hamilton $\mathrm{G}$, Kurtaran A, et al. Imaging gastrointestinal tumours using vascular endothelial growth factor-165 (VEGF165) receptor scintigraphy. Ann Oncol 2003;14:1274-7.

32. Li S, Peck-Radosavljevic M, Kienast O, Preitfellner J, Havlik E, Schima W, et al. Iodine-123-vascular endothelial growth factor165 (123I-VEGF165). Biodistribution, safety and radiation dosimetry in patients with pancreatic carcinoma. Q J Nucl Med Mol Imaging 2004;48:198-206.

33. Yoshimoto M, Kinuya S, Kawashima A, Nishii R, Yokoyama K, Kawai K. Radioiodinated VEGF to image tumor angiogenesis in a LS180 tumor xenograft model. Nucl Med Biol 2006;33:963-9.

34. Blankenberg FG, Mandl S, Cao YA, O'Connell-Rodwell C, Contag C, Mari $\mathrm{C}$, et al. Tumor imaging using a standardized radiolabeled adapter protein docked to vascular endothelial growth factor. J Nucl Med 2004;45:1373-80.

35. Blankenberg FG, Backer MV, Levashova Z, Patel V, Backer JM. In vivo tumor angiogenesis imaging with site-specific labeled (99m)Tc-HYNIC-VEGF. Eur J Nucl Med Mol Imaging 2006;33:841-8.

36. Chan C, Sandhu J, Guha A, Scollard DA, Wang J, Chen P, et al. A human transferrin-vascular endothelial growth factor (hnTfVEGF) fusion protein containing an integrated binding site for (111)In for imaging tumor angiogenesis. J Nucl Med 2005;46: $1745-52$.

37. Presta LG, Chen H, O'Connor SJ, Chisholm V, Meng YG, Krummen L, et al. Humanization of an anti-vascular endothelial growth factor monoclonal antibody for the therapy of solid tumors and other disorders. Cancer Res 1997;57:4593-9.

38. Nagengast WB, de Vries EG, Hospers GA, Mulder NH, de Jong JR, Hollema $\mathrm{H}$, et al. In vivo VEGF imaging with radiolabeled bevacizumab in a human ovarian tumor xenograft. J Nucl Med 2007;48:1313-9. 
39. Stollman TH, Scheer MG, Leenders WP, Verrijp KC, Soede AC, Oyen WJ, et al. Specific imaging of VEGF-A expression with radiolabeled anti-VEGF monoclonal antibody. Int $\mathrm{J}$ Cancer 2008;122:2310-4.

40. Nagengast WB, Lub-de Hooge MN, Hospers GA, Brouwers AH, Hoekstra HJ, Elsinga PH, et al. Towards clinical VEGF imaging using the anti-VEGF antibody bevacizumab and Fab-fragment ranibizumab. J Clin Oncol 2008;26: Abstract 3547.

41. Folkman J. Angiogenesis in cancer, vascular, rheumatoid and other disease. Nat Med 1995;1:27-31.

42. Cheresh D. Integrins: structure, function and biological properties. Adv Mol Cell Biol 1993;6:225.

43. Aumailley M, Gurrath M, Müller G, Calvete J, Timpl R, Kessler H. Arg-Gly-Asp constrained within cyclic pentapeptides. Strong and selective inhibitors of cell adhesion to vitronectin and laminin fragment P1. FEBS Lett 1991;291:50-4.

44. Gurrath M, Müller G, Kessler H, Aumailley M, Timpl R. Conformation/activity studies of rationally designed potent antiadhesive RGD peptides. Eur J Biochem 1992;210:911-21.

45. Haubner R, Gratias R, Diefenbach B, Goodman S, Jonczyk A, Kessler H. Structural and functional aspects of RGD-containing cyclic pentapeptides as highly potent and selective integrin alphavbeta3 antagonists. J Am Chem Soc 1996;118:7461-72.

46. Haubner R, Wester H-J, Reuning U, Senekowitsch-Schmidtke R, Diefenbach B, Kessler H, et al. Radiolabeled alphavbeta3 integrin antagonists: a new class of tracers for tumor targeting. J Nucl Med 1999;40:1061-71.

47. Haubner R, Wester H-J, Burkhart F, Senekowitsch-Schmidtke R, Weber W, Goodman S, et al. Glycosylated RGD-containing peptides: tracer for tumor targeting and angiogenesis imaging with improved biokinetics. J Nucl Med 2001;42:326-36.

48. Haubner R, Kuhnast B, Mang C, Weber W, Kessler H, Wester H-J, et al. [18F]Galacto-RGD: synthesis, radiolabeling, metabolic stability, and radiation dose estimates. Bioconjug Chem 2004;15: 61-9.

49. van Hagen PM, Breeman WA, Bernard HF, Schaar M, Mooij CM, Srinivasan A, et al. Evaluation of a radiolabelled cyclic DTPARGD analogue for tumour imaging and radionuclide therapy. Int $\mathbf{J}$ Cancer 2000;90:186-98.

50. Assa-Munt N, Jia X, Laakkonen P, Ruoslahti E. Solution structures and integrin binding activities of an RGD peptide with two isomers. Biochemistry 2001;40:2373-8.

51. Su ZF, Liu G, Gupta S, Zhu Z, Rusckowski M, Hnatowich DJ. In vitro and in vivo evaluation of a technetium-99m-labeled cyclic RGD peptide as a specific marker of alpha(V)beta(3) integrin for tumor imaging. Bioconjug Chem 2002;13:561-70.

52. Su ZF, He J, Rusckowski M, Hnatowich DJ. In vitro cell studies of technetium-99m labeled RGD-HYNIC peptide, a comparison of tricine and EDDA as co-ligands. Nucl Med Biol 2003;30: 141-9.

53. Sivolapenko GB, Skarlos D, Pectasides D, Stathopoulou E, Milonakis A, Sirmalis G, et al. Imaging of metastatic melanoma utilising a technetium-99m labelled RGD-containing synthetic peptide. Eur J Nucl Med 1998;25:1383-9.

54. Costopoulos B, Varvarigou AD, Sivolapenko G, Potamianos S, Scopinaro F, Archimandritis SC. Radiochemical and radiobiological evaluation of a synthetic peptide labelled with $99 \mathrm{Tcm}$. Nucl Med Commun 1997;18:474.

55. Lindsey ML, Escobar GP, Dobrucki LW, Goshorn DK, Bouges S, Mingoia JT, et al. Matrix metalloproteinase-9 gene deletion facilitates angiogenesis after myocardial infarction. Am J Physiol Heart Circ Physiol 2006;290:H232-9.

56. Hua J, Dobrucki L, Sadeghi M, Zhang J, Bourke B, Cavaliere P, et al. Noninvasive imaging of angiogenesis with a $99 \mathrm{mTc}$-labeled peptide targeted at alphavbeta3 integrin after murine hindlimb ischemia. Circulation 2005;111:3255-60.

57. Bach-Gansmo T, Bogsrud TV, Skretting A. Integrin scintimammography using a dedicated breast imaging, solid-state gamma- camera and (99m)Tc-labelled NC100692. Clin Physiol Funct Imaging 2008;28:235-9.

58. Bach-Gansmo T, Danielsson R, Saracco A, Wilczek B, Bogsrud $\mathrm{TV}$, Fangberget $\mathrm{A}$, et al. Integrin receptor imaging of breast cancer: a proof-of-concept study to evaluate $99 \mathrm{mTc}-\mathrm{NC} 100692$. J Nucl Med 2006;47:1434-9.

59. Axelsson R, Bach-Gansmo T, Castell-Conesa J, McParland BJ, Study Group. An open-label, multicenter, phase 2a study to assess the feasibility of imaging metastases in late-stage cancer patients with the alpha $\mathrm{v}$ beta 3 -selective angiogenesis imaging agent 99mTc-NC100692. Acta Radiol 2010;51:40-6.

60. Janssen M, Oyen WJ, Massuger LF, Frielink C, Dijkgraaf I, Edwards DS, et al. Comparison of a monomeric and dimeric radiolabeled RGD-peptide for tumor targeting. Cancer Biother Radiopharm 2002;17:641-6.

61. Behr TM, Goldenberg DM, Becker W. Reducing the renal uptake of radiolabeled antibody fragments and peptides for diagnosis and therapy: present status, future prospects and limitations. Eur J Nucl Med 1998;25:201-12. Review.

62. Janssen ML, Oyen WJ, Dijkgraaf I, Massuger LF, Frielink C, Edwards DS, et al. Tumor targeting with radiolabeled alpha(v)beta (3) integrin binding peptides in a nude mouse model. Cancer Res 2002;62:6146-51.

63. Dijkgraaf I, Kruijtzer JA, Liu S, Soede AC, Oyen WJ, Corstens $\mathrm{FH}$, et al. Improved targeting of the alpha(v)beta (3) integrin by multimerisation of RGD peptides. Eur J Nucl Med Mol Imaging 2007;34:267-73.

64. Boturyn D, Coll JL, Garanger E, Favrot MC, Dumy P. Template assembled cyclopeptides as multimeric system for integrin targeting and endocytosis. J Am Chem Soc 2004;126:5730-9.

65. Dijkgraaf I, Rijnders AY, Soede A, Dechesne AC, van Esse GW, Brouwer AJ, et al. Synthesis of DOTA-conjugated multivalent cyclic-RGD peptide dendrimers via 1,3-dipolar cycloaddition and their biological evaluation: implications for tumor targeting and tumor imaging purposes. Org Biomol Chem 2007;5:935-44.

66. Wang L, Shi J, Kim YS, Zhai S, Jia B, Zhao H, et al. Improving tumor-targeting capability and pharmacokinetics of $(99 \mathrm{~m}) \mathrm{Tc}$ labeled cyclic RGD dimers with PEG(4) linkers. Mol Pharm 2009;6:231-45.

67. Shi J, Wang L, Kim YS, Zhai S, Liu Z, Chen X, et al. Improving tumor uptake and excretion kinetics of $99 \mathrm{mTc}$-labeled cyclic arginine-glycine-aspartic (RGD) dimers with triglycine linkers. J Med Chem 2008;51:7980-90.

68. Shi J, Kim YS, Chakraborty S, Zhou Y, Wang F, Liu S. Impact of bifunctional chelators on biological properties of (111)In-labeled cyclic peptide RGD dimers. Amino Acids 2010 Jan 6. [Epub ahead of print].

69. Pini A, Viti F, Santucci A, Carnemolla B, Zardi L, Neri P, et al. Design and use of a phage display library. Human antibodies with subnanomolar affinity against a marker of angiogenesis eluted from a two-dimensional gel. J Biol Chem 1998;273:21769-76.

70. Demartis S, Tarli L, Borsi L, Zardi L, Neri D. Selective targeting of tumour neovasculature by a radiohalogenated human antibody fragment specific for the ED-B domain of fibronectin. Eur J Nucl Med 2001;28:534-9.

71. Santimaria M, Moscatelli G, Viale GL, Giovannoni L, Neri G, Viti $\mathrm{F}$, et al. Immunoscintigraphic detection of the ED-B domain of fibronectin, a marker of angiogenesis, in patients with cancer. Clin Cancer Res 2003;9:571-9.

72. Berndorff D, Borkowski S, Moosmayer D, Viti F, Müller-Tiemann $\mathrm{B}$, Sieger $\mathrm{S}$, et al. Imaging of tumor angiogenesis using $99 \mathrm{mTc}-$ labeled human recombinant anti-ED-B fibronectin antibody fragments. J Nucl Med 2006;47:1707-16.

73. Chengazi VU, Feneley MR, Ellison D, Stalteri M, Granowski A, Granowska M, et al. Imaging prostate cancer with technetium99m-7E11-C5.3 (CYT-351). J Nucl Med 1997;38:675-82. 
74. Chang SS, O'Keefe DS, Bacich DJ, Reuter VE, Heston WD, Gaudin PB. Prostate-specific membrane antigen is produced in tumor-associated neovasculature. Clin Cancer Res 1999;5:267481.

75. Chang SS, Reuter VE, Heston WD, Bander NH, Grauer LS, Gaudin PB. Five different anti-prostate-specific membrane antigen (PSMA) antibodies confirm PSMA expression in tumorassociated neovasculature. Cancer Res 1999;59:3192-8.
76. Morris MJ, Divgi CR, Pandit-Taskar N, Batraki M, Warren N, Nacca A, et al. Pilot trial of unlabeled and indium-111-labeled anti-prostate-specific membrane antigen antibody J591 for castrate metastatic prostate cancer. Clin Cancer Res 2005;11:7454-61.

77. Morris MJ, Pandit-Taskar N, Divgi CR, Bender S, O’Donoghue JA, Nacca A, et al. Phase I evaluation of J591 as a vascular targeting agent in progressive solid tumors. Clin Cancer Res 2007;13:2707-13. 